\title{
Primary Pre-service Teachers' Perspectives on Constructivism and its Implementation in the Schools
}

\author{
Savaş Baştürk \\ Elementary Mathematics Teacher Education, Sinop University, Turkey
}

Copyright $\subset 2016$ by authors, all rights reserved. Authors agree that this article remains permanently open access under the terms of the Creative Commons Attribution License 4.0 International License

\begin{abstract}
The aim of this study was to determine pre-service teachers' perspectives on constructivism and its implementation in schools. In order to do this, a semi-structured interview was conducted with 12 primary pre-service teachers from the grades 2, 3, and 4. Four pre-service teachers were voluntarily selected from each grade for interview. Each interview lasted about 20 minutes. The recorded interviews were transferred to written texts and later analyzed. The responses were examined by descriptive and content analysis. According to the most significant results of the research, the pre-service teachers' knowledge of constructivism is general, theoretical, and limited. Although they are very positive about constructivism as a teaching and learning approach, they have major hesitations in its implementation in the schools due to the lack of experience in such an approach during their education and the lack of motivation for constructivism resulting from the weaknesses of knowledge. The pre-service teachers also think that the lessons and practices in the faculty of education are not very sufficient to become a constructivist teacher.
\end{abstract}

Keywords Constructivism, Primary Pre-service
Teachers, Teacher Training

\section{Introduction}

Many philosophers and researchers have tried to explain the nature of learning for decades. Constructivism is one of the results of this effort. As it does not put forward hypothesis to be tested and generated, constructivism is not viewed as a theory, but as an epistemology or philosophical explanations aiming to determine how we learn $[1,2]$. Even though its predictions are very general and can differently be interpreted, there are many researches which focus on them.

Constructivism considers learning as a process by which students structure their knowledge by changing or rejecting ideas they already have $[3,4,5]$, and does not limit thinking only to the mind. Thinking cannot separately be considered from situations and individuals largely construct cognitions by basing on their experiences in these situations [6, 7]. The individuals' contributions to what is learned are not negligible and the culture and social environments in which individuals interact with others are also important in acquisition of skills and knowledge [8]. According to Paparozzi [9], "constructivism centers on the student, involves problem solving, requires the student to interpret and elaborate, recognizes the student as having prior knowledge, encourages interaction socially and with the environment, and views errors as opportunities to learn" (p. 48). By referring to Paparozzi's classification and the relevant literature, we can identify some main principles of the constructivism as follows:

Constructivism takes students to the centre: This refers to well-designed experiences where students can play an active role. A well-designed experience means that meaning is indexed and rooted in experience which will be realized by students. The experience which leads students to achieve an idea has an extremely important role in understanding and employing that idea. Thus, to understand and determine whether the learning occurred, the experience is a significant indicator. From the hypothesis that every student constructs a unique understanding, the student-centred approach requires that all students need to have the experience themselves. For the constructivist teachers, the quality of learning is more important than the quantity of learning, therefore they firstly focus on the student not the topic [10].

Constructivism includes problem-solving: Doing mathematics does not mean only knowing to directly apply definitions, theorems and properties, but engaging in activities which require solving problems by utilizing these definitions, theorems and properties [11]. Problem-solving allows students to construct concepts and to apply them to problematic situations. This therefore gives them an opportunity to go beyond given information or to develop their own ideas. The problem situations designed for students should reflect the real life outside the classroom. If its degree is well adjusted, students can easily use their abilities in other problem-solving situations.

Constructivism asks students to interpret and elaborate: The active learner is an important component in 
constructivism [12]. This means that the learners should not be contented with being an active processor of knowledge, but they should interpret and elaborate upon the knowledge. In this context, what is expected from the students is to internalize knowledge by processing, but not to have a bank of knowledge by accumulating.

Constructivism takes into account students' prior knowledge: According to constructivism, students construct meaning by based on their prior knowledge. If the material has non meaning in students' background, we cannot expect that they completely learn it. The students do not come to the classroom as a blank sheet of paper, but with their knowledge and experiences which are spontaneously and informally obtained from their social environment. By recognizing it, the teachers should take into consideration students' prior knowledge. In a way, the quality of a meaning constructed by the students is largely based on that of correlations between new and prior knowledge.

Constructivism encourages the environmental and social interactions: The social negation of understanding and meaning is emphasized in constructivism. As one of the main purposes of constructivism is to provide students to transfer their knowledge into the real life situations, the environment resulting in learning in the classroom should eventually be correspondent with the complexity of the target environment. According to Spiro [13], the non-existence of transfer is often a conclusion of the significant difference between the environments school and non-school. Perkins [14] associates the realization of authentic transfer with the condition that the complexity of the environment is conserved and one helps students to understand the concepts which take place in this environment. According to Watts and Jofili [10], the constructivist teachers therefore encourage social interactions, meaningful experiences and provide students to elaborate on what they already know.

Constructivism considers students' errors as opportunities for learning: One of the biggest differences between constructivism and traditional views appears in the approach to student's errors. The traditional teaching and learning approaches consider students' mistakes or errors as insufficient work, not well-listening to teachers' discourse or lack of knowledge which prevents students to commit these mistakes. Mistakes are often seen as a failure of the student's knowledge that a well learning should avoid [15]. In contrast to this perspective, the constructivists identify that mistakes are not something to be avoided; on the contrary they are necessary for learning. According to Brousseau [16], the mistakes play a significant role in detecting an obstacle, but these mistakes do not result from chance. They are reproducible and persistent. As constructivism underlines the negotiations between the student and the knowledge, mistakes can be employed by the teachers as a tool to determine students' thinking. In this context, Watts and Jofili [10] indicate that the constructivist teachers consider scientific knowledge as a result of many attempts and changeable, therefore they are tolerant about the students' mistakes.

\subsection{The Purpose of the Study}

One of the biggest obstacles to implement constructivism in teaching is that many teachers have difficulties in overcoming their traditional approaches to education [9]. As teachers and administrators believe that the implementation of constructivism requires no goal and lesson plan, but it can be realized only with an individualized education for every child, they are afraid of constructivism [17].

In the society we live, we often hear that the proverb "one cannot walk without crawling" is used for the individuals who want to immediately get some things. This means that the realization of these things takes time. Therefore, expecting an individual to immediately modify his/her learning and teaching understanding is not reasonable. According to Paparozzi [9], the objectivist teachers do not or should not try to immediately implement all constructivist methods in their classes without providing students to feel comfortable in this educational model and quietly guiding them so as to insure success and thus increase confidence and competence.

The teachers' decisions have important results on students' learning. Thus, the most important role in establishing constructivist learning environments surely belongs to them. If we aim that constructivist principles are correctly implemented by teachers in their classrooms, they should graduate from teacher training programs by being well-equipped with required knowledge and skills. As indicated above, the implementation of constructivism is not easy and takes time. Therefore, teachers, especially beginner teachers, are faced with some challenges of this subject. According to Hart [18], as their experiences affect their thinking and actions in their teaching, pre-service teachers should first-hand encounter constructivist learning both as learners and as planners. One of the places where pre-service teachers can have such experiences of implementing constructivism is of course the faculty of educations. Therefore, the purpose of this study was to determine the pre-service teachers' perspectives on constructivism and its implementation in the schools. Through the study, we aimed to consider that pre-service teachers graduate from the faculty with what perspectives.

\section{Materials and Methods}

As the aim of this study was to understand a problem in detail by supporting on data from a small number of pre-service teachers, narrative inquiry, one of the forms of qualitative research, was adopted. Field texts, such as stories, autobiography, journals, field notes, letters, conversations, interviews, family stories, photos, and life experiences are considered by narrative inquiry as the units of analysis to research and understand the way people create meaning in 
their lives as narratives [19]. In this study, the main objective was to present a realistic picture related to the research problem rather than to obtain results that can be generalized through numbers. Therefore, the obtained data is limited to only the pre-service teachers participating in the study.

\subsection{The Participants}

The study participants involved 12 pre-service teachers who were enrolled in the department of primary school teacher education in the faculty of education of a state university in the north of Turkey. They were selected on a voluntary basis. It was aimed that the pre-service teachers from all grades except the first grade were included in the study. The reason of excluding the first grade was that the pre-service teachers' experiences in this grade were not yet sufficient to respond some questions of the interview.

\subsection{Data Collection and Analysis}

As data collection instrument, a semi-structured interview was used in the study. The questions of the interview form were prepared by the researcher from the relevant literature [e.g., 9, 20, 21], his experiences on teacher training area, and informal interviews conducted with pre-service teachers. Before conducting interviews, three experts having a doctorate of education examined the interview form and confirmed that it was suitable for the research purpose. Semi-structured interviews were conducted in relaxed environments, lasted about 20 minutes, and tape-recorded. Then, the records were transcribed and analysed by means of document analysis which is one of the qualitative research methods. The interview schedule consisted of ten questions with the aim of determining pre-service teachers' perceptions.

During the analysis process, we first classified the pre-service teachers' responses and then determined categories. By always comparing the categories with each other, we identified the common categories [22]. To transform qualitative data into quantitative, we calculated frequency of the categories. The inter-coder reliability of the open-ended questions of the interview was determined by the researcher and two faculty members from the department of primary school teacher education. Using Miles and Huberman's [23] formula, it was calculated $92.25 \%$.

\section{Results}

In this section, the results of the analysis of the pre-service teachers' responses to the questions are presented. The questions having the same purpose will be taken together.

\subsection{Pre-service Teachers' General Perceptions of Constructivism}

In the interview form, there were two questions that aim to determine the pre-service teachers' general perceptions of constructivism. The first one asked them to indicate the first three things coming in their mind when saying constructivism. In the pre-service teachers, constructivism mainly evokes student-centred learning (10 Pre-service Teachers). This is followed by being active (6 PTs) and discover (2 PTs). The following excerpts help us to better understand the mentioned results:

\section{In my opinion, constructivism means student-centred learning. The teacher is rather in position of a guide and director. Besides, the student has the opportunity to discover him/her own talents (Pre-service Teacher1). \\ When saying constructivism, student-centred learning and an approach in which the student is active but the teacher is passive, come in my mind. The main role of the teacher is to guide the students in their learning (PT3).}

In both comments, we consider that the pre-service teachers underline student-centred learning and draw our attention to the role of teacher in the learning by associating it with that of a guide or director. On the other hand, the first indicates that constructivism offers students to realize their capabilities while the second considers constructivism as an approach in which the student is more active than the teacher.

The second question asked the pre-service teachers to express their general thoughts about constructivism. The majority of them view constructivism as necessary for a permanent learning (11 PTs). 5 pre-service teachers believed that it cannot completely be implemented. Although their number is limited, some pre-service teachers considered the problem of time (1 PT), the lack of knowledge (1 PT) and some various problems (1 PT) as barriers to implement constructivism in teaching. The following extracts were typical of such comments:

I believe that constructivism is a good approach. I hope that when I become a teacher, I will use it. Opposite to the rote learning, constructivism is an approach requiring students to actively participate in learning environment with their own feelings and thoughts. Knowledge cannot directly be transferred into the students, but it can be discovered by themselves with examples from the daily life. Every topic should concretely be taught to students (PT4).

My thoughts about constructivism are generally positive. For example, the fact that it takes students to the centre and acts according to them, are one of its advantages. However, it takes a lot of time. An activity based on constructivism may consume one hour of lesson. Therefore, the learning objectives cannot be sufficiently implemented or remain incomplete (PT9).

When it is really implemented and the students are active, constructivism has great significance. But, its well-application is very difficult (PT3). 
I am positive about constructivism, but I am not sure that it is completely understood by the teachers. In my opinion, most of the teachers have not sufficient knowledge on constructivism (PT12).

The comments indicate that the pre-service teachers are positive about constructivism because it emphasizes the importance of student-centred learning and teaching environments. However, they have some anxieties about its well-implementation. Some of them believe that constructivism needs a lot time. Therefore, the teacher may have problems in finishing the curriculum on time. Furthermore, one of the biggest obstacles to the implementation of constructivism is the teachers' weaknesses of knowledge about constructivism.

\subsection{Constructivism and Teachers}

In the interview protocol, there were two questions that address to express the relationship between constructivism and teacher. Thus, one of these questions aimed to determine the characteristics of a constructivist teacher according to the pre-service teachers, while the other was destined to identify the causes that prevent to be a constructivist teacher. The pre-service teachers mentioned six characteristics of constructivist teacher. According to them, a constructivist teacher should include students in the lesson (6 PTs), respect students' needs and interests (5 PTs), motivate them to think (3 PTs), prepare suitable activities and materials to teaching (3 PTs), avoid to directly present knowledge and be a guide (3 PTs), and renew him/herself (1 PT). This is supported by some pre-service teachers' comments, as illustrated below:

If a teacher respects students' needs and interest, takes them into account, teaches by preparing activities and engaging students in the lessons, this is an indication that s/he adopts a constructivist teaching approach (PT4).

If a teacher takes student to the centre, acts according to the level of student, gives importance to his/her needs, s/he is constructivist (PT9).

If a teacher engages all students, including slow learners, in teaching, in my opinion this teacher is constructivist. I believe that if s/he teaches by implementing different teaching techniques and methods such as the question-answer method, the problem solving method etc., in addition of the direct instruction, s/he is a constructivist teacher (PT11).

If a teacher motivates students to think, encourages them to be productive, helps them to transfer theoretical knowledge into practise, and permanently teaches, in my opinion s/he becomes a constructivist teacher (PT10).

In the comments, we consider that the pre-service teachers qualify as a constructivist teacher if $\mathrm{s} / \mathrm{he}$ includes students in teaching, takes their feels, levels and needs into account when planning his/her teaching, implements different teaching methods to the direct instruction, and carries students to think and to be productive.

As regards the results of the analysis of the other question, the pre-service teachers consider as a barrier to be a constructivist teacher, the received training ( 8 PTs), the personal opinions and wishes (5 PTs), the lack of knowledge (4 PTs), and the social-environmental factors and deficiencies of learning environment (2 PTs). This is supported by the interview comments, as illustrated below:

(...) It may a bit result from the personality or the way in which the teacher is trained. For example, now we are trained according to constructivist approach and get an education in that manner. However, it is difficult to expect teachers, especially experienced teachers who have never seen this type of education, that they implement it in their classes. In my opinion, this is one of the most important causes (PT7).

Their own teachers have a significant impact on the teachers. Therefore, it is normal that teachers want to implement what they see from their teachers. Knowing theoretically constructivism is not sufficient to implement it. Sure, knowing is important, but not sufficient. Therefore, it is also necessary to see its applications and to apply it (PT10).

Teachers may not know what constructivism completely is. They are not also able to know that if what they make, they behave in accordance with constructivism. They may be deprived of suitable environments. Furthermore, implementing constructivism also requires getting some opportunities such as economical. However, the most important cause is the lack of full knowledge of constructivism (PT11).

The comments underline that only taking theoretical knowledge about constructivism is not sufficient to be a constructivist teacher. It is very important that the pre-service teachers are trained with respect to the constructivist approach, and they take lessons from the lecturers adopting this approach.

\subsection{Pre-service Teachers' Beliefs on the Implementation of Constructivism in the Schools}

We asked the pre-service teachers two questions to determine their beliefs on the implementation of constructivism in the schools and whether they implement constructivism in their teaching when they become a teacher. A majority of the pre-service teachers argue that constructivism cannot be implemented in the schools because of various causes (10 PTs). These causes result from the teachers (5 PTs), the realities of the country ( 3 PTs), the lack of time and the overcrowding of classes (1 PT), and the unsuitable learning environments (1 PT). The following extracts are typical of such comments: 
I do not obviously think a lot that constructivism is implemented in the schools. In elementary school, it was not applied and now it is also the same for the university. Lecturers go into the classroom and lecture their lessons by only using the direct instruction method. I do not believe that we participate very much in the lessons. Why? Since we saw this way in the elementary and secondary school, now we have difficulties in participating in the lessons even our lecturers insist too much. Therefore, in my opinion, it is necessary to start constructivist teaching and learning from the level of elementary school (PT6).

As far as I have seen until now, the number of teachers who implement constructivism in the schools is very limited. One of its biggest reasons is that the teachers are old. In general, they are strictly linked to the traditional teaching methods. This prevents them from adopting constructivism (PT9).

I do not believe that constructivism can be implemented in overcrowded classes. This approach requires particularly looking after every child. Because, it is the main principle of student-centred constructivist approach. Teacher should know their students with their all sides. In my opinion, this is impossible in overcrowded classes (PT10).

I do not believe that in Turkey constructivism can actually be applied. Because, there are many disadvantages that vary from the unsuitable learning environment to the lack of materials (PT11).

According to the comments, it can be asserted that the pre-service teachers are not very optimistic that constructivism can be implemented in the schools. Their reasons are as follows: the teachers are not trained with a constructivist approach from the elementary school to the university, the teachers in schools are old and thus they have difficulties in adopting new teaching approach such as constructivism, and the classes are too crowded.

We consider that almost all the pre-service teachers indicate that they will implement constructivism in their teaching (11 PTs). Some pre-service teachers explain how to do it such as: preparing materials and concretizing topics (3 PTs), orienting students and employing technology (3 PTs), and using different teaching and learning methods ( $3 \mathrm{PTs}$ ). On the other hand, there are two pre-service teachers who do not believe the implementation of constructivism because of some reasons. One of them argues that constructivism cannot be implemented at the level of elementary school while the other one thinks there will be problems in practice as long as the age of teacher is advanced. The following comments illustrated this type of causes:

I will absolutely implement constructivism in my teaching. Firstly I won't be a teacher who adopts behaviourist approach. I will indulgently behave my student and I will perceive them as individuals. All their ideas will be very important and valuable for me. In my teaching, I will use different methods and techniques and materials (PT7).

If I can be a teacher, sure I try to use constructivism. I will implement it by preparing teaching activities based on materials, including students in teaching, and using methods such as the question-answer method (PT5).

Most of the teachers in the practice schools are very experienced and do not use too much materials in their lessons. They tell us that they also were idealist like us when they started teaching profession, but they lose this idealism over time. This gives me the idea that we will be like them in the following years. Sure, I know that only the use of materials is not sufficient to be a constructivist teacher. I think to implement constructivism by being a guide to students and including them in teaching. For instance, instead of directly giving a formulas, I will provide students to discover it themselves (PT8).

I will implement it, because constructivism has too much influence on education. In the teaching and learning, I defend and adopt very much the constructivist approach. An individual can forget, a knowledge that s/he theoretically learnt, some days after. However, if knowledge is presented by linking with everyday life, it will be more permanent and won't easily be forgotten (PT10).

The comments determine that the pre-service teachers plan to implement constructivism when they become a teacher. One of them seems to be negatively affected by the bad examples in the practice schools and she is afraid of losing his idealism. Linking topics with everyday life, being a guide to students, including them in teaching, respecting their differences are among the implementation forms mentioned by the pre-service teachers.

\subsection{Effectiveness of the Lessons and Practices in the Faculty of Education in Terms of Constructivism}

To identify the effectiveness of the lessons and practices in the faculty of education from a viewpoint constructivist, we asked the pre-service teachers two questions. The first one focus on the lessons and practices while the second one focus on the processing of lessons according to constructivism. Only two pre-service teachers positively respond to the first question and state that the lessons and practices are conducted in accordance with constructivism. The other responses are as follows: I believe that it is not enough (7 PTs), there are deficiencies with respect to the application (5 PTs), the lessons are not aimed at the teacher training (4 PTs), and third grade is more suitable for the constructivist approach (2 PTs). These following extracts will clarify the student teachers' points:

I believe that none of the given lessons in our faculty serve in the teacher training, because at the university there is still an air of high school. Students only think to pass the exams, but not how to be an effective teacher. 
Lecturers should convince students that the exams are passed in any case and being an effective teacher is really important (PT2).

The number of the lecturers who implement constructivism in their teaching is too limited. According to constructivism, a new knowledge is constructed by both the teacher and the student. However, until now what we do in some lessons is completely the memorization. Therefore, for some lessons, I cannot say that the constructivist approach is fully implemented (PT9).

This depends a little on pre-service teachers' willingness to implement constructivism and their self-development. I think that some of among the lessons we take contribute to have a constructivist approach. Especially in education lessons, our lecturers ask us to teach lessons. This provides us an opportunity to implement the constructivist approach. In my opinion, it is enough and sure open to be further developed (PT7).

The lessons are more theoretically conducted in first and second grades, but third grade mostly passes with practice applications. However, because many teachers in the practice schools do not implement constructivism in their teaching, I am obviously afraid of being like them over time. After so much effort, it is a shame that we also continue the traditional approach (PT11).

In the comments, the pre-service teachers consider to be limited the lessons and practices in the faculty of education in terms of constructivism. In their opinion, pre-service teachers only think to pass the exams instead of making an effort to be an effective teacher. The lessons are based on theoretical knowledge and so the lecturers' assessment approaches lead pre-service teachers to the memorization. Some lessons, especially education lessons of third and fourth academic years, can be viewed as constructivist. Their experiences in the practice schools also negatively affect them and they are frightened to be a traditional teacher like many practice school teachers.

The pre-service teachers' views on conducting the lessons in the faculty suitable for constructivism are as follows: Six of them argue that the lessons are not conducted in accordance with constructivism, while four distinguish some lessons from others. There are three pre-service teachers who indicate that it varies according to lecturers' teaching and learning understanding. All this was reflected in the following extracts:

I do not absolutely believe that the lessons are conducted in accordance with constructivist approach. Most of the lecturers seem to adopt a traditional approach to teaching and learning. In many points, we have shortcomings. For instance, we are not aware of how to use the body language. In my opinion, it is very important for a teacher. When we teach a subject in front of students or classmates, we are very excited. Here, we are only taught some knowledge, but not how to teach them (PT2).

I do not believe that constructivism is very much adopted by the lecturers. I think it is implemented only in our education courses. Especially the unique teaching method implemented by the lecturers in first and second grades is the direct instruction. In my opinion, these grades should also be focused on education courses (PT3).

One day, one of our lecturers said us "I am a traditional teacher, but you will not, you will work to be a constructivist teacher, because you are not a child." Here it is the implementation of constructivism in our faculty (PT1).

Even though there are exceptions, the direct instruction method is often implemented by the lecturers. They always ask us to adopt constructivist approach in our teaching, but should they firstly be a model of constructivist teacher? That is, they can do themselves, what they always ask us (PT5).

The comments tell us that the constructivism is not sufficiently implemented by the lecturers. Most of the lecturers often ask the pre-service teacher to adopt constructivism in teaching, but it seems like that they are very far from being an example in this subject.

\section{Discussion and Conclusion}

In this study, we examined the primary pre-service teachers' perspectives on constructivism and its implementation in the schools through the data obtained from the semi-structured interviews. Research studies have reported that the ways (pre-service) teachers implement their instructional approaches are strongly linked to their beliefs [24-26]. Therefore, it can be supposed that in the context of modifying and improving pre-service teachers' perspectives, the present study will contribute to teacher training programs. The main results obtained from the study can be presented as follows:

When saying constructivism, the pre-service teachers' first reactions focus on three common words: student-centred learning, being active, and discover. By basing on the principles of constructivism identified by Paparozzi [9], we remark that its other components such as problem-solving, taking into account students' prior knowledge, consideration of students' errors as opportunities for learning, and environmental and social interactions are not sufficiently emphasised by the pre-service teachers. We can therefore conclude that their knowledge on the constructivist learning principles is limited. Consistent with this finding, in another recent study carried out with the biology pre-service teachers on constructivist learning approach and applicability in 
secondary education, Köse, Gül and Konu [27] also identified that constructivist learning theory was not known by the pre-service teachers. Because it encourages student-centred learning, gives a role of guide to the teacher, and helps students to become aware of their capabilities, the pre-service teachers generally have a very favourable impression of constructivism. This finding is in line with that of Çınar, Teyfur and Teyfur's [28] study being conducted with primary school teachers and administrators to determine their views on constructivism and the curriculum in use. They identified that the participants' views on constructivism were in general positive, and the lacks of infrastructure of schools were considered as a barrier to the well-implementation of constructivism.

On the other hand, the pre-service teachers have some anxieties about the implementation of constructivism as required. The need for more time and the teachers' lack of knowledge about constructivism are at the top of these anxieties. By considering that the pre-service teachers largely obtain these impressions from the practice schools, it can be asserted that the teachers there do not completely know constructivism or they cannot implement it in their teaching due to the intensity of curriculum. However, because of the pre-service teachers' other statements about practice school teachers, the second assumption seems not to be reasonable.

As regards how the pre-service teachers define a constructivist teacher, in their opinion, if a teacher provides students to take part in teaching, plans his/her teaching according to students' feelings, needs, and academic levels, implements different teaching methods, and helps students to reason and be productive, s/he can be identified as a constructivist teacher. Furthermore, some of the pre-service teachers indicate that having theoretical knowledge about constructivism cannot guarantee to be a constructivist teacher and teacher educators should therefore be a role model for pre-service teachers in this subject.

The pre-service teachers do not think very positively about the practicality of constructivism in schools. The factors that force them to believe in this way are that teachers have never experienced such an education approach from the primary school to the university, the majority of teachers in schools are elderly and thus they have difficulties in overcoming their traditional teaching and learning approaches, and the overcrowding of classes. In the study they conducted complete survey of both literature concerning studies within teacher education that promote constructivism from 1990-2003 and thirty-five studies from constructivist classrooms, Dangel and Guyton [29] identified some components of constructivism. One of them is extensive field experiences. This component is therefore very important and largely refers to practice school experiences. The more the gap between the faculty and the practice schools increases, the more pre-service teachers have problems in adopting what they learned. In the practice schools, pre-service teachers need to experience a rich process in the engagement with mentors' pedagogical discourse and reflective thinking [30-32]. Although in Turkey the process in which teachers are assigned as monitor is not sufficiently systematic [33], mentoring is not a work which can be left to chance $[34,35]$. As we considered it in the pre-service teachers' comments, in fact mentors who are not open to the news and reforms and not willing to change their traditional teaching and learning approach negatively affect pre-service teachers' beliefs in and attitudes towards constructivism.

On the other hand, when being assigned to a teacher, the pre-service teachers indicate that they will implement constructivist learning principles in their classroom. Associating subjects to be covered with real life situations, including students in teaching, playing the role of a guide in teaching environments, and respecting individual differences are some of the main ways of their implementation of constructivism.

The pre-service teachers think that the lessons and practices in the faculty of education are not very sufficient to become a constructivist teacher. They support this idea with the following reasons: many pre-service teachers are not aware of the importance of becoming a constructivist teacher and they only think to pass the exams by getting a passing grade. The lessons are theoretically taught by mostly using the direct instructional method, and thus this produces a teaching and learning understanding based on the memorization. The lecturers more frequently insist that the pre-service teacher implement constructivism in their teaching practices, but they cannot be an example in this regard. In his study conducted with the secondary school mathematics pre-service teachers, Baştürk [36] also underlined their complaints about the weakness of their lecturers in modelling constructivism to them. This indicates that the problem is not only restricted to the research group of the present study. As well underlined by Aldrich and Thomas [37], since teacher educators has a responsibility to model and showcase constructivism to pre-service teachers who may have never encounter this type of approach during their own student years, they should not neglect constructivism. In addition, the fact that in the practice schools they encounter teachers who can be qualified as a bad example with regard to constructivism decreases the pre-service teachers' motivation for implementing it in future.

As a result, it can be concluded that the pre-service teachers' knowledge of constructivism is general, theoretical, and limited. Although they are very positive about constructivism as a teaching and learning approach, they have major hesitations in its implementation in the schools due to the lack of experience in such an approach during their education and the lack of motivation for constructivism resulting from the weaknesses of knowledge. As the present study is limited to the pre-service teachers' responses to the questions, one cannot predict how they transform this theoretical and general knowledge into practice. Therefore, in further studies, it would be very interesting to include the pre-service teachers' instructional practices in the research 
design in order to examine the extent of relevance of their perspectives for practice.

\section{Acknowledgements}

An early version of this research was presented in IX. European Conference on Social and Behavioural Sciences. The author would like to thank the pre-service teachers who participated in this study for their collaboration.

\section{REFERENCES}

[1] Hyslop-Margison, E. J., \& Strobel, J. (2008). Constructivism and education: Misunderstandings and pedagogical implications. The Teacher Educator, 43, 72-86.

[2] Simpson, T. L. (2002). Dare I oppose constructivist theory? The Educational Forum, 66, 347-354.

[3] Bransford, J.D., Brown, A.L., \& Cocking, R.R. (1999). How people learn. Washington, DC: National Academy Press.

[4] Cobb, P. (1994). Where is the mind? Constructivist and sociocultural perspectives on mathematical development. Educational Researcher, 23(7), 13-20.

[5] Driver, R., Asoko, H., Leach, J., Mortimer, E., \& Scott, P. (1994). Constructing scientific knowledge in the classroom. Educational Researcher, 23(7), 5-12.

[6] Bredo, E. (1997). The social construction of learning. In G. Phye (Ed.), Handbook of academic learning: The construction of knowledge (pp. 3-45). New York: Academic Press.

[7] Cobb, P., \& Bowers, J. (1999). Cognitive and situated learning perspectives in theory and practice. Educational Researcher, 28(2), 4-15.

[8] Schunk, D. H. (2012). Learning theories: An educational perspective. ( $6^{\text {th }}$ Edition) Boston: Pearson.

[9] Paparozzi, C. (1998). Implementing constructivism in the middle school classroom (Order No. 9926671). Available from ProQuest Dissertations \& Theses Global. (304454690). Retrieved from http://search.proquest.com/docview/3044546 90 ?accountid $=25096$

[10] Watts, M., \& Jofili, Z. (1998). Towards critical constructivist teaching. International Journal of Science Education, 20(2), 173-185, DOI: 10.1080/0950069980200204.

[11] Brousseau, G. (1986). Fondements et méthodes de la didactique. Recherches en Didactique des Mathématiques, 7 (2), 33-115

[12] Perkins, D.N. (1992). Technology and constructivism: do they make a marriage? Constructivism and the Technology of Instruction. Hillsdale, NJ: Lawrence Erlbaum Associates, Publishers.

[13] Spiro, R. (1988). Cognitive flexibility theory: advanced knowledge acquisition in ill-structured domains. (Tech. Rep. No. 441) Champaign, Illinois: Centre for the Study of Reading.
[14] Perkins, D.N. (1989). Art as understanding. Art, mind, and education: Research from project zero. Urbana, IL: University of Illinois Press.

[15] Henry, M. (1991). Didactique des mathématiques : une présentation de la didactique en vue de la formation des enseignants [Mathematics education: an introduction to teaching for teacher training]. Besançon: IREM de Besançon.

[16] Brousseau, G. (1983). Les obstacles épistémologiques et les problèmes en mathématiques [Epistemological obstacles and problems in mathematics]. Recherches en Didactique des Mathématiques, 4(2), 164-198.

[17] Dick, W. (1992). An instructional designer's view of constructivism. Constructivism and the Technology of Instruction. Hillsdale, NJ: Lawrence Erlbaum Associates.

[18] Hart, L. C. (2002). Preservice teachers' beliefs and practice after participating in an integrated content/methods course. School Science \& Mathematics, 102, 4-15.

[19] Clandinin, D. J., \& Connelly, F. M. (2000). Narrative inquiry: Experience and story in qualitative research. San Francisco: Jossey-Bass Publishers.

[20] Çetin, P. S., Kaya, E., \& Geban, Ö. (2014). Students', pre-service teachers' and in-service teachers' views about constructivist implementations. Necatibey Faculty of Education Electronic Journal of Science and Mathematics Education, 8(2), 143-163.

[21] Gill, L. A. (2005). Personal narratives and constructivism in teacher education (Order No. 3167273). Available from ProQuest Dissertations \& Theses Global. (304987359). Retrieved from http://search.proquest.com/docview/3049873 59? accountid $=25096$

[22] Creswell, J.W. (1998). Qualitative inquiry and research design: Choosing among five traditions. Thousand Oaks, CA: Sage.

[23] Miles, M., \& Huberman, M. (1994). Qualitative data analysis: An expanded sourcebook (2nd ed.). Thousand Oaks, CA: Sage.

[24] Crawford, B. A. (2007). Learning to teach science as inquiry in the rough and tumble of practice. Journal of Research in Science Teaching, 44, 613-642.

[25] Richmond, G., \& Anderson, C. (2003). The nature of tensions between educator and teacher candidate beliefs about science teaching practice. Paper presented at the National Association for Research in Science Teaching, Philadelphia, March.

[26] Toy, K. L. (2013). Preservice teachers engaging with social constructivism in elementary classrooms (Order No. NS27710). Available from ProQuest Dissertations \& Theses Global. (1504616336). Retrieved from http://search.proquest .com/docview/1504616336?accountid $=25096$

[27] Köse, E.Ö., Gül, Ş., \& Konu, M. (2014). Yapılandırmacı öğrenme yaklaşımı ve ortaöğretimde uygulanabilirliği hakkında öğretmen adaylarının görüşleri [The prospective teachers' opinions about constructivist learning approach and applicability in secondary education]. The Journal of Academic Social Science, 2(2/1), 84-95.

[28] Çınar, O., Teyfur, E. \& Teyfur, M. (2006). İlköğretim okulu ögretmen ve yöneticilerinin yapılandırmacı eğitim yaklaşımı ve programı hakkındaki görüşleri [Primary school teachers 
and administrators' views on constructivist learning approach and curriculum]. Inönü University Journal of Faculty of Education. 7(11). 47-64.

[29] Dangel, J. \& Gutyon, E. (2003). Expanding our view of teaching and learning: applying constructivist theory(s) to teacher education. Paper presented at the Annual Meeting of the American Association of Colleges for Teacher Education, New Orleans, LA (ERIC Document Reproduction Service No. ED472816).

[30] Barnett, B. G. (1995). Developing reflection and expertise: Can mentors make the difference? Journal of Educational Administration, 33(5), 45-59.

[31] Crowther, D. T., \& Cannon, J. R. (1998). How much is enough? Preparing elementary science teachers through science practicum. Paper presented at the Annual Meeting of the Association for the Education of Teachers of Science, Minneapolis, MN, January.

[32] Healy, L., Ehrich, L. C., Hansford, B., \& Stewart, D. (2001). Conversations: a means of learning, growth and change. Journal of Educational Administration, 39(4), 332-345.

[33] Baştürk, S. (2010). Uygulama öğretmenlerine göre okul deneyimi grubu dersleri ve ögretmen adayları [According to mentors the group of school experience courses and pre-service teachers]. Gazi Üniversitesi Türk Ĕ̈itim Bilimleri Dergisi [Gazi University Journal of Turkish Educational Sciences]. 8(4), 869-894.

[34] Carter, M., \& Francis, R. (2000). Mentoring and beginning teachers' workplace learning. Paper presented at the Australian Association of Research in Education (AARE) Conference, Sydney, Australia.

[35] Ganser, T. (1996). What do mentors say about mentoring? Journal of Staff Development, 8(2), 113-126.

[36] Baştürk, S. (2011). Matematik Öğretmen Adaylarının Eğitim Fakültesindeki Eğitim-Öğretim Sürecini Değerlendirmeleri. [Mathematics Teacher Candidates' Evaluations of Teaching and Learning Process in Faculty of Education] International Journal of Human Sciences 8(1), 58-94.

[37] Aldrich, J. E., \& Thomas, K. R. (2002). Evaluating the diverse constructivist beliefs of early childhood, elementary, and middle school education majors. Paper presented at the Annual Meeting of the Mid-Western Educational Research Association, Columbus, OH (ERIC Document Reproduction Service No. ED472815). 